\title{
MYTH, UTOPIA, AND POLITICAL ACTION
}

\author{
IRIS MENDEL
}

\begin{abstract}
Starting from the premise that some form of "reality transcendence", i.e. the ability to imagine a different reality and reach out for the (un)thinkable, is necessary for political action, the aim of this paper is to analyse the concepts of myth and utopia elaborated by Georges Sorel and Karl Mannheim and to examine their possible contributions to a theory of political action and social change. By comparing the role the authors assign to rationality and irrationality in human affairs, methodological and conceptual differences between Sorel's and Mannheim's approaches to the political are illustrated. It turns out that due to its immunity to critique Sorel's concept of the social myth is highly problematic. Mannheim's concept of utopia, on the other hand, culminates in a technocratic understanding of the political. Though both approaches emphasise the collective dimension of political action, they ultimately exhibit elitist understandings of the political.
\end{abstract}

Keywords: myth; utopia; political action; social change.

\section{Introduction}

Why do people engage in political action? How does political radicalization occur? And when does political engagement lead to real social change? Obviously, political action would be meaningless, if people did not believe in their power to actually change the ways in which their societies and lives are organised. This belief is grounded in the crucial human ability to think reality differently, to transcend the given and immediate and grasp for the seemingly impossible and unreachable. "Man [!] is the only living being who consciously can split reality in two: into the existent and the other," writes Frederik L. Polak $(1966,282)$. It is exactly this "other" where myth and utopia are to be found, the "other" of a world of facts and figures which find their way into historiography.

Being able to transcend reality is a crucial characteristic which Karl Mannheim ascribes to utopias. However, even in transcending reality, utopias are like all mental acts and forms of knowledge in Mannheim's sociology of knowledge still "existentially connected", i.e. influenced by a concrete social and historical situation. Utopias are not arbitrary thought experiments, but expressions of concrete dissatisfactions and desires. Similarly, Frank and Fritzie Manuel $(1979,24)$ point out that "utopia is tied to existing social conflicts" and that it "can be studied as a reflection of the specific crisis that it presumes to resolve". Myths too flourish in times of fundamental ruptures and offer possibilities of interpreting and reinterpreting perturbing events. By providing allcomprising theories that seem to restore some kind of lost totality in society and, accordingly, by introducing images that arouse strong emotions among people, utopia 
and myth are able to wake the belief that it is possible to change the existing social and political conditions - and the aspiration to do so. In this respect myth and utopia seem effective devices for political mobilisation and collective action. This is the role Georges Sorel and Karl Mannheim ascribe to myth and utopia, respectively. However, except for their shared belief in some form of human agency, there seem to be little communalities between Sorel's concept of myth most famously elaborated in his Reflections on Violence (1908/1914) and Mannheim's concept of utopia which was introduced in opposition to ideology in his major work Ideologie und Utopie (1929/1936). These two works seem to offer the first sociological elaboration of myth and utopia. In the following comparison of these two concepts, I will examine what they have to offer a theory of political action and social change.

\section{Sorel's Concept of the Social Myth as Call to Action}

Sorel's notion of myth is intrinsically tied to social change. Responding to questions about the integration of individuals into effective unities capable of creative action in history, Sorel's conception could even be regarded as a theory of revolution, as Hans Barth $(1959,70)$ suggests: The notion of the myth is aiming at mass movement, myth and mass are connected. According to Sorel (1961a, 50), the construction of a myth is crucial for social movements because a

myth cannot be refuted, since it is, at bottom, identical to the convictions of a group, being the expression of these convictions in the language of movement; and it is, in consequence, unanalysable into parts which could be placed on the plane of historical descriptions.

Thus, the myth appears as indomitable image, as undividable whole evoking strong emotions among a collective of people. This is crucial because, for Sorel, political commitment is a matter of emotions rather than of rational deliberation. Neither utilitarian considerations nor the intellect are sufficient calls to action, because it is not abstract concepts but images that really activate people. Therefore, only the social myth is capable of political mobilisation.

An effective myth seeks out the hidden aspirations of a group and can thus become a source of motivation and an object of faith (Flood 2002, 72). Being an object of belief rather than of the intellect, the myth becomes incredibly powerful. Since people are willing to sacrifice themselves for objects of their faith rather than for objects of their reasoning, as Sorel (1961a, 44-5) illustrates with reference to the cases of Giordano Bruno and Galileo Galilei, the faith in the myth can push people to pass over their limits. Consequently, the commitment to "great causes" may justify all kinds of means, including violence. Indeed, the means may become ends, action as such an absolute value. As Edward Shils $(1961,15)$ confirms, for Sorel,

the highest good is heroic (i.e. aggressive) action performed with a sense of impersonal consecration to the ends of a restricted, delimited group bound together in fervent solidarity and impelled by a passionate confidence in its ultimate triumph in some cataclysmic encounter. 
It is the myth which is binding together this group, for only the myth creates the mass by uniting people for a common cause and motivating them to collective action. This points to the practical intention of Sorel's concept of myth, namely to give a theoretical foundation to what Sorel believed to be the decisive motor of social and political change in his own time: the general strike, or rather: the myth of the general strike.

Sorel's notion of myth can be understood as a theory of social action, assigning a crucial role to non-rational factors in human action. ${ }^{1}$ It is the process of rebellion, the revolutionary act per se which is important for Sorel, not what comes after it. The myth is an image of an enormous catastrophe that can only flourish in times of crisis, announcing the coming of a new society, but keeping silent about how this new society will look like. This puts the myth in sharp contrast to utopia, which "can be discussed like any other social constitution" (Sorel 1961a, 50) and evaluated in the course of history. Utopia is the embodiment of everything Sorel abhors. Not surprisingly, he establishes his concept of myth in opposition to the concept of utopia, which for Sorel is an "intellectual product" remote from the interests of the masses. Utopia is thus the means for reformers; myth the weapon for revolutionaries. Myth is the contrary of utopia: not the design of an ideal society to be realised in some undefined future, but a call to heroic action in the very present. Action, the main focus of Sorel's theoretical ambitions, seems to be strictly excluded by the intellectualist constructs of utopians. In this respect, Sorel's notion of utopia differs fundamentally from the one of Karl Mannheim.

\section{Mannheim's Concept of Utopia as Transcendence and Transformation of Reality}

It is generally agreed upon that the first systematic examination of utopia as a mode of thinking began with Mannheim in his major work Ideologie und Utopie, in which Mannheim introduces ideology and utopia as two possible reality transcending orientations. Ideology and utopia are both representations of a consciousness which do not fully correspond with reality. Whereas ideology pictures an idealised reality and is thus stabilizing the status quo, utopia seeks to overthrow the existing order. Thus, contrary to Sorel, Mannheim conceives of utopia as intrinsically tied to social action. Of course, Mannheim is aware that also ideologies may function as motives for action, but due to their falsehood they never do so in the pretended direction. Contrary to ideologies, utopias succeed in transforming a particular historical reality according to their own ideas.

Interestingly, the definition of utopia as "revolutionizing ideal" strongly resembles Sorel's concept of myth which he so vehemently sought to oppose to utopia. However, while Sorel is concerned with the role of myth in motivating and mobilising social action, Mannheim's concept of utopia is defined by its effective power to transform reality:

Only those orientations transcending reality will be referred to by us as utopian which, when they pass over into conduct, tend to shatter, either partially or wholly, the order of things prevailing at the time (Mannheim 1991, 173).

\footnotetext{
${ }^{1}$ Sorel's emphasis on the psychological and emotional side of action has to be understood in the context of Bergsons's philosophy of life, rejecting utilitarian notions and concentrating on the inner states of mind in the creative moment of action.
} 
Thus, the concept of utopia relies on the actual consequences of social action and can, strictly speaking, only be defined ex post, i.e. after utopia has become reality. Representing not only the will, but also the power to change present conditions, utopia is the driving force in history. Accordingly, politics cannot be thought of without utopia.

This is particularly true in times of democratic competition which forces all social groups to become utopian, since they can only survive if they develop a project of transformation. As Ricoeur (1986, 275) emphasises, ideologies and utopias do not exist as long as a common culture is not broken. Since utopias are defined as antagonistic to each other, drawing their dynamic character from the ongoing competition between them, the concept of utopia makes only sense in the plural for Mannheim. For his own time, he differentiates four different forms of the utopian consciousness: the chiliastic utopia of the Anabaptists, the liberal-humanitarian idea, the conservative idea and the socialist-communist utopia. According to Mannheim, these utopias can only be understood in relation to each other. All political groups and intellectual programmes are inevitably drawn into the dialectic of utopia and counter-utopia; hence, form and content of the particular utopias are dependent on and change with the dynamics of the inter-group relations (Turner 2003, 38). However, there is one utopia which sets this dynamic into motion and is therefore coming closest to an ideal type of utopia: the chiliastic utopia. Forming an alliance with the aspirations of repressed groups, the chiliastic utopia reorients hopes from the hereafter to the here and now and can therefore be regarded as the starting point of modern politics (Mannheim 1995, 185).

Interestingly, the most ideal typical utopia in Mannheim's concept has remarkable similarity to Sorel's notion of myth. Both, in Sorel's myth and Mannheim's chiliastic utopia, orgiastic energies aim at demolishing the existing order. These energies, not rational considerations or abstract ideas, lead to social action and eventually to revolution. And just like the social myth, the chiliastic utopia relies on images and symbols in order to arouse the energies which it needs to encourage social action. Taking into consideration these similarities, one may assume that it was exactly Sorel's notion of myth which Mannheim had in mind when he described his ideal type of utopia. Indeed, Mannheim explicitly states anarchism and syndicalism as main heirs of the chiliastic utopia. Yet Mannheim deliberately avoided the term "myth" when talking about effective political change. According to him (1995, 78 and 179), the main function of myths is to stabilise the contingent conditions of everyday life by expressing what a particular reality does not contain via wishful projections; but they do not strive to decompose this reality as utopias do. Thus, the myth has the same static and conservative function as ideology, but it differs from ideology because it is irrational, whereas ideology is a rationalisation of the status quo (Halpern 1961, 141). Also Sorel's emphasis on action and struggle finds a counterpart in Mannheim's concept of utopia as motor of political action and social change. Considering the German version (with the first and the last chapter of the English version missing) one can easily see the strong weight assigned to the chapter on utopia. Therefore Bryan Turner (1991, xlvii) regards Ideologie und Utopie as "a study of revolutionary politics" and Colin Loader $(1985,95)$ suggests that it "was a call to action".

Indeed, Mannheim conceives of utopia as being essential for society. It is not utopia in the singular which can fulfil this task, but rather the ongoing antagonism between the different utopias. Hence, the disappearance or weakening of any single utopia has 
negative effects for the historic dynamic. Yet Mannheim observes precisely this happening: an ongoing "absorption" of utopia. All utopias seem to be approaching a conservative attitude finding some arrangement with the existing conditions and thus cease to be utopian. The initial representation of reducing the gap between their own ideas and reality is thus realised in a paradox way: not by raising real conditions to a higher ideal, but by approximating formerly high ideals to reality. On the one hand, Mannheim takes a negative stance to this development. Whereas he has a positive vision of a "postideological society" (Remmling 1975, 73), he fears that the destruction of the utopian element in society would lead to a matter-of-factness perishing human will altogether. On the other hand, he $(1995,220)$ considers this realism as appropriate attitude in the present situation arguing that in times of high social tensions it is simply necessary to debunk both ideology and utopia. This somewhat overhasty conclusion, however, makes only sense if social conflicts are reduced to an opposition of ideas, ignoring all material interests involved-a highly reductionist view of social conflicts which deprives sociology of knowledge of its material base.

\section{Rationality and Irrationality in Human Action}

One of the most profound differences between Mannheim's and Sorel's approaches concerns the role which they assign to rationality. Though Mannheim is clearly no adherent of rationalism (as philosophical doctrine), his writings are still in the tradition of the Enlightenment. Mannheim wanted to save the possibility of studying society in a rational way by providing an appropriate sociological base. In this context, he introduced the concept of the free-floating intelligentsia. Though he conceives of human affairs as to a large extent irrational, they can still be studied in a rational way. Sorel, however, seems to have broken with the Enlightenment values of rationality, progress and intellectualism. His concept of myth withdraws itself from being analysed, because the myth is not a rational construct, but a call to action.

Action, as it seems, is something deeply irrational for Sorel, motivated by emotions rather than by rational calculations. At least, social action cannot be studied theoretically, for any abstraction from the concrete act necessarily implies generalisations simplifying the complexity of human agency. Sorel's formulates this rejection of reductionism in the study of social affairs as a critique of Cartesian rationalism and its construction of abstract and general patterns (e.g., in the theory of "the human") which are then applied to the real world (Kolakowski 1978, 156). Sorel refuses to develop any general characterisation and restricts himself to emphasise the activist and irrational elements in human affairs. Sorel rejects any rational planning of the revolution in favour of a more spontaneous attempt motivated by myth. For him (1961, 238), revolution ought to be concerned with the "organization of hands, while utopianism wished only to advise the head of industry".

In this context, the revolutionary power inherent in the concept of myth becomes clear. Myths are capable of social mobilisation

by embodying a dynamic vision of the movement of life, the more potent because not rational, and therefore not subject to criticism and refutation by university wiseacres (Berlin 1980, 327). 
Having a vivid image of the future and believing in the possibility to realise this image is thus more powerful in bringing about social change than rational persuasion. For Sorel, rational argumentation detracts from political action and results in conservative passivity. Sorel does not want arguments pointing at real constraints and causing doubts to interfere in the revolutionary action of the masses. It does not matter to him whether a myth is true or not, as long as it is believed to be true by the masses. Actually, a myth may be able to motivate social action precisely by distorting reality. In fact, Sorel is convinced that in particular actions which effectively change reality, such as strikes and revolutions, would often not have taken place if people had known the real conditions. Sorel seems to believe that all historically effective action springs from misapprehensions and delusion (Grünwald 1934, 14). But this illusion attached to action is no problem for Sorel who defines the act as absolute and hence not criticisable. Accordingly, the social myth must not be judged by reality, but has to be measured in terms of its effectiveness in motivating action. Thus the value of an assertion is no longer assessed by its truth, but by its function. This inversion of values, which was most prominently represented by Nietzsche, marks Sorel's strongest break with Enlightenment ideas. Instead, Sorel introduces a pragmatist notion of truth, with truth being not dependent on the validity of a belief, but on its usefulness. ${ }^{2}$ Since the truth of myth is subordinate to its function, myth becomes immune to rational argument. Argument has to give way to belief; reality to myth.

However, Sorel does not completely discard the notion of truth. Indeed, he (1961a, 62) emphasises in the introduction to his Reflections on Violence that his writings "are inspired by a passionate love of truth", which "has become a rare enough quality". But due to convenience people generally renounce the possibility of knowledge. In this context, Sorel's pragmatist notion of truth turns up, which seems to be the dominant notion in everyday life. According to Sorel, people need some idea about the surrounding social environment, in order to get along in everyday life. Because they are too lazy to develop an exact perception, they base their imaginative representation on projections from popular concepts. Thus, for Sorel, the creation of myths is caused by the intellectual laziness of the average person. Sorel is not interested in turning popular belief into a rational conception of reality (as, for example, Gramsci would be), but rather draws on the delusions of the mythical consciousness in order to mobilise the masses. Hence, the revolution turns out to be the business of the myth maker who exactly knows how to mobilise the intellectually lazy masses. Despite its emphasis on mass mobilisation, Sorel's theory of political action and social change turns out to be an elitist conception.

The emphasis on the irrational elements in human affairs is a consequence of a scientific movement which altered the simple models of human nature dominant in classical social and political philosophy. The concession that non-rational and unconscious factors play a crucial role in human action challenged the idea of the rational subject. This shift in the perception of human nature corresponds to the shift from classical political theory to more deterministic and descriptive disciplines

\footnotetext{
${ }^{2}$ Not surprisingly, the pragmatist psychologist William James was one of the main intellectual influences of Sorel.
} 
beginning with Tocqueville and Marx and carried on by Weber, Durkheim, Pareto and Freud (Berlin 1980, 324). Both, Sorel and Mannheim, are exponents of the latter tradition. Sorel developed a political theory which concedes human irrationality a crucial role in social and political affairs. In this respect, he can be regarded a "forerunner of the sociology of knowledge" (Horowitz 1961, 126). This brings Sorel closer to Mannheim, who is usually regarded as the founder of sociology of knowledge.

Arguing that knowledge is existentially connected, Mannheim too abandons the notion of the abstract individual capable of gaining "pure" knowledge. Since Mannheim states that it is the social conditions which influences the emergence as well as the form of knowledge, he was criticised for reducing knowledge to society, with the former being a mere manifestation of the latter. This concept of knowledge "as epiphenomenon of social being" would indeed imply the end of autonomous human agency, as Simonds $(1978,30)$ points out. However, according to Mannheim $(1964,613)$ the existential connectedness of knowledge does not negate the possibility of knowledge altogether. He recognises the irrational elements in thought, but attempts to encounter them in a rational way in the framework of his sociology of knowledge as the theoretical base for a science of politics (Kettler/Meja/Stehr 1990, 1441).

Referring to Schäffle, Mannheim (1995, 98-100) divides the social-political life into two aspects: current state affairs and politics. The former describes the execution of certain issues according to some existent rules; the latter implies active decisions based on one's own judgement. In analogy to this distinction, Mannheim resolves social affairs into a rationalised ${ }^{3}$ and an irrational domain. This distinction is the context of his definition of action. According to Mannheim, the execution of some task in the rationalised realm is merely reproductive because it does not show any active personal involvement. Action is only possible within the irrational scope in which not everything is regulated and decision making hence necessary. Here action and politics start. But is there any knowledge about the irrational domain and the possible forms of action within it, Mannheim goes on to ask. In this context, the link between a science of politics and sociology of knowledge becomes obvious. Who else could have reliable knowledge about politics but the intellectuals, who, according to Mannheim, are able to detach themselves from the immediate involvement in political affairs and to overview and evaluate the different positions? Therefore, they are the ones to provide the necessary knowledge for politics, a task politicians are too involved to fulfil. Thus, the sociology of knowledge seems to be "somehow central to any strategy for creating a rapprochement between politics and reason" (Kettler/Meja/Stehr 1984, 29) or between theory and praxis, for it enables the participants in the political process to reorientate themselves in the social and political world and to adjust their actions accordingly. However, the role of political sociology cannot be to actually make, but only to prepare political decisions (Mannheim 1995, 143).

Does Mannheim thus only start his analysis with a definition of politics as active process, while proceeding with an understanding of politics that eventually yields passivity? Is political action reserved to the professional politicians with both

\footnotetext{
${ }^{3}$ Mannheim uses the term "rationalisation" in Max Weber's sense of bureaucratic regulation. See Weber (1995).
} 
intellectuals and the masses being excluded from it? As it turns out, the intellectuals are not only restricted to an advisory role with regard to the politicians, but also relegated to a mediating position with regard to the masses. The task of the intellectuals is to warrant that the political world including political practice is governed by reason. This guaranty of reason at the expense of spontaneous action finally culminates in Mannheim's writings on social planning.

But politics is not merely created by the head, as Max Weber $(1992,80)$ points out in his famous treatise Politik als Beruf. Politics is also a matter of passion. Accordingly, Weber defines passion, sense of responsibility and judgement as decisive qualities for the politician. Furthermore, Weber $(1992,70)$ differentiates two kinds of ethics involved in politics which seem to be relevant for Sorel's and Mannheim's notions of political action: the ethic of responsibility (Verantwortungsethik) and the ethic of ultimate ends (Gesinnungsethik). The ethic of responsibility corresponds with a predominantly rational notion of politics. Having no illusions about human nature or society, the responsible politician considers human defects when planning political agency and is ready to account for its possible consequences. Thus, the ethic of responsibility reduces politics to Realpolitik, not leaving much room for visionary (or utopian) ambitions. In the ethic of ultimate ends, on the contrary, these ambitions become absolute, while possible consequences of the acts aimed at realising the postulated ends are not considered.

It is no coincidence that Weber $(1992,71)$ mentions syndicalism in this context. Indeed, Sorel's notion of the myth of the general strike clearly fits in Weber's description of the ethic of ultimate ends. Sorel even succeeds this notion by renouncing any ultimate end except for action itself. With action being means and end at the same time, however, there is no possibility of measuring the one in terms of the other. Since there is no independent end, Sorel does obviously not allow for rational action, which for Weber is characterised by focussing on some end (which may be an object as well as a value) and adapting one's action accordingly. At the same time, it is precisely Sorel's image of the human as "defective" (i.e. intellectually lazy), which Weber sees as characteristic for the ethic of responsibility, that accounts for the effectiveness of the myth.

It is harder to integrate Mannheim's concept of utopia and his related notion of political action in Weber's typology. On the level of the four different utopias, Mannheim certainly accounts for affective and non-rational aspects of human action. However, when leaving the level of describing the antagonism between the different utopias and turning to the intellectual synthesis necessary for a science of politics, Mannheim clearly focuses on the rational aspect of social action. Being able to overlook society in its totality and thus to give reliable judgements, the intellectuals act in accordance with what Weber called the ethic of responsibility.

In Sorel's understanding of politics action is the unquestionable absolute; Mannheim, on the contrary, abandons his initially active concept of politics in favour of a rationalised one disregarding human agency. While Mannheim attempts to rationalise the irrational by intellectual means to support political affairs, Sorel draws on the irrational in order to inspire political action culminating in the total revolution. Sorel's concept of political action is closer to Weber's affective action based on the ethic of ultimate ends; Mannheim starts with a very complex concept of political action, but finally waters it down to a rational approach based on the ethic of responsibility. 
However, though their approaches to as well as their understandings of politics differ considerably, Sorel and Mannheim (in his earlier works) share a crucial conviction: both believe that it is necessary to reach out for the impossible in order to realise the possible, as Weber's $(1992,82-3)$ famous definition of the political vocation maintains.

\section{Conclusion}

The main intention in this paper was to examine whether political action and social change rely on some form of reality transcendence as it is offered by the concepts of myth and utopia. In order to change the status quo one has to leave the "here and now", at least mentally. Both Sorel's concept of the social myth and Mannheim's theory of utopia reflect this understanding of the political, though in different ways. For Sorel, myths are means for acting on the present, while not caring much about the future. In this point, myth radically differs from utopia: myths "depict the future, not as possible order, but as catastrophic event" (Tudor 1972, 15). The myth is thus a vehicle in the battle, impelling to act, while leaving aside pragmatic considerations. This strong tie to political action is also a basic characteristic of Mannheim's concept of utopia. In fact, Horowitz $(1961,110)$ notes

that Mannheim's use of the term "utopian" is like Sorel's use of the term "myth"; that is, the perception and intuition of the total framework of future society.

Indeed, Mannheim defines utopia as reality transcending principle that is actually capable of transforming reality eventually. For Mannheim, utopia is an important political force because it enables to channel and focus political engagement. The resulting dynamic antagonism between the different utopias is crucial for the historical process. This historical process can only be understood by a group that is not directly involved in the main antagonisms of the time: the free-floating intellectuals. Though Mannheim initially "thought he discovered the avant-garde of utopia in the radicalized intelligentsia" (Boudon/Bourricaud 1989, 428), he drops this notion when talking about the intellectual synthesis of the different utopian programmes, which, according to him, is necessary for the analysis of society and a science of politics. Led by his own historical experiences of the First and the Second World War, Mannheim turned to a rational concept of politics and increasingly restricted the utopian element in his later works on social planning. Signs of this shift can already be observed in Ideologie und Utopie. Here Mannheim starts off with a dynamic definition of politics, but concludes with a rationalised notion of politics as almost scientific agenda of some functional elite advised by intellectuals. This understanding of the political which curtails human agency dramatically, however, is the end of a development which Mannheim $(1995,236)$ saw very critically in the first place. Mannheim's initial concern that "with the relinquishment of utopias, man [sic!] would lose his will to shape history and therewith his ability to understand it," reflects the reality of the implication of his own theory, namely that in the end, the ability to understand and to create history is reserved to a small elite.

Sorel, on the contrary, sticks to his concept of the social myth. Reflecting and encouraging irrational impulses and energies, there is no need for the myth to become rational. Since the myth cannot be analysed, it is not open for critique or revision. This 
points to a fundamental difference between Mannheim's utopia and Sorel's myth with the former being a rational construct, open for critique. By introducing a concept of myth which eludes all categories of right and wrong, good and evil, just and unjust, Sorel provided the theoretical framework for ideologies founded on instinct, such as fascism. Sorel replaced the "progressive illusion that the end justifies the means because the ends are certified ... by a rebellion in which the means become the end" (Stanley 1981, 334). Since the rebellious movement displaced the end in Sorel, his theory can be taken up by any political orientation. Sorel himself exemplified this political arbitrariness inherent in his theory by shifting from the syndicalist left to the extreme right. Sorel may provide valuable insights in the working of political myths by pointing at the fact that they are powerful precisely because they are irrational and immune to critique, as the fascist myth of the Aryan race exemplarily showed. However, turning this descriptive insight into a normative claim is highly problematic and not compatible with an emancipatory understanding of the political.

Mannheim, on the contrary, was precisely concerned with the problem of studying irrational facets of social affairs in a rational way. His concept of utopia is open for rational argument. Indeed, mutual criticism is inherent in Mannheim's notion of utopias as antagonistic forces. Hence Mannheim's pluralistic understanding of utopia seems to satisfy the need for political orientation and focus in an increasingly complex and contradictory world. However, precisely the contradictions inherent in existent societies make Mannheim's concept of the political synthesis based on a total view of society problematic. This is the critique of the Frankfurt School arguing that the

very goal of total knowledge ... betrayed an underlying acceptance of the classical German Idealist notion of a transcendent subject capable of a harmonious, all-embracing view of the whole. Such a hypostatized subject did not, indeed could not, exist in a contradictory world (Jay 1974, 81).

Hence, the free-floating intellectuals could not "really attain a total view of truth, for truth did not reside in the totality, at least not yet" (ibid.). The political synthesis (or utopia in the singular) has to remain utopian in a contradictory world.

Thus, despite designing concepts of the political based on collective engagement in the first place, both, Mannheim's and Sorel's approaches ultimately exhibit elitist understandings of the political: with the myth being the business of some mythmaker in Sorel and the intellectuals being the guarantors of reason in political affairs in Mannheim. Whereas Sorel failed to distinguish his attack on rationalism from an attack on reason in general, reflected in his fascination for fascism, Mannheim's pluralist notion of utopia finally gives way to a rather technocratic conception of the political, reflected in his later works on social planning.

\section{References}

Barth, H. Masse und Mythos, Die Ideologische Krise An Der Wende Zum 20. Jahrhundert Und Die Theorie Der Gewalt: Georges Sorel. Hamburg: Rowohlt, 1959.

Berlin, I. Georges Sorel. In H. Hardy (Ed.). Against the Current, Essays in the History of Ideas. London: Hogarth Press, 1980. 
Boudon, R., Bourricaud, F. A Critical Dictionary of Sociology. London: Routledge, 1989.

Flood, Ch. G. Political Myth. London: Routledge, 2002.

Grünwald, E. Das Problem der Soziologie des Wissens. Versuch einer kritischen Darstellung der wissenssoziologischen Theorien. Wien, Leipzig: Wilhelm Braunmüller, 1934.

Halpern, B. "Myth" and "Ideology" in Modern Usage. History and Theory 1,2, 129-149, 1961.

Horowitz, I. L. Radicalism and the Revolt against Reason. The Social Theories of Georges Sorel. London: Routledge and Kegan Paul, 1961.

Jay, M. The Frankfurt School's Critique of Karl Mannheim and the Sociology of Knowledge. Telos 20, 72-89, 1974.

Kettler, D., Meja, V., Stehr, N. Karl Mannheim. Chichester and London, New York: Ellis Horwood Limited and Tavistock Publications, 1984.

Kettler, D., Meja, V., Stehr, N. Rationalizing the Irrational: Karl Mannheim and the Besetting Sin of German Intellectuals. American Journal of Sociology 95, 6, 1441-1473, 1990.

Kolakowski, L. Main Currents of Marxism, Its Rise, Growth and Dissolution. Vol. II: The Golden Age. Oxford: Clarendon Press, 1978.

Loader, C. The Intellectual Development of Karl Mannhei. Culture, Politics, and Planning. Cambridge [etc.]: Cambridge University Press, 1985.

Mannheim, K. Die Bedeutung der Konkurrenz im Gebiete des Geistigen. In K. H. Wolff (Ed.). Wissenssoziologie: Auswahl aus dem Werk. Neuwied: Luchterhand, 1964.

Mannheim, K. Freedom, Power and Democratic Planning. London: Routledge \& Kegan, 1950.

Mannheim, K. Ideologie und Utopie. Frankfurt am Main: Vittorio Klostermann, 1995.

Mannheim, K. Ideology and Utopia. An Introduction to the Sociology of Knowledge. London, New York: Routledge, 1991.

Manuel, F. E., Manuel, F. P. Utopian Thought in the Western World. Oxford: Basil Blackwell, 1979.

Polak, F. L. Utopia and Cultural Renewal. In F. E. Manuel (Ed.). Utopias and Utopian Thought. Boston, Cambridge: Houghton Mifflin Company, The Riverside Press, 1966.

Remmling, G. W. The Sociology of Karl Mannheim. London: Routledge \& Kegan Paul, 1975.

Ricoeur, P. Lectures on Ideology and Utopia. New York: Columbia University Press, 1986.

Shils, E. A. Introduction to the American Edition. In G. Sorel. Reflections on Violence. New York: Collier Books, 1961.

Simonds, A. P. Karl Mannheim's Sociology of Knowledge. Oxford: Clarendon Press, 1978.

Sorel, G. Decomposition of Marxism. In I. L. Horowitz. Radicalism and the Revolt against Reason. The Social Theories of Georges Sorel. London: Routledge and Kegan Paul, 1961.

Sorel, G. Reflections on Violence. New York: Collier Books, 1961a.

Stanley, J. The Sociology of Virtue. The Political and Social Theories of George (sic) Sorel. Berkley, Los Angeles, London: University of California Press, 1981.

Tudor, H. Political Myth. London: Basingstoke, Macmillan Press, 1972.

Turner, B. S. Preface to the new Edition. In Karl Mannheim. Ideology and Utopia. An Introduction to the Sociology of Knowledge. London, New York: Routledge, 1991.

Turner, Ch. Mannheim's utopia today. History of the Human Sciences 16, 1, 27-47, 2003.

Weber, M. Politik als Beruf [1919]. Stuttgart: Reclam, 1992.

Weber, M. Wirtschaft und Gesellschaft [1922]. In M. Weber. Schriften zur Soziologie. Stuttgart: Reclam, 1995.

Department of Philosophy of Science

University of Vienna

and International Research Center for Cultural Studies, Vienna, Austria

E-mail: mendel@ifk.ac.at 